\title{
Early adolescent girls' expectations about the fit of clothes: A conceptual framework
}

\author{
Thea Tselepis and Helena M de Klerk
}

\section{OPSOMMING}

Met in agneming van die probleme wat die SuidAfrikaanse kledingindustrie en veral kleinhandelaars tans in die oog staar, is dit duidelik dat, ten einde te kan oorleef, kleinhandelaars gefokus moet kompeteer met ander wat saam met hulle in die mark werk. Vir meeste kleinhandelaars is dit ' $n$ prioriteit om verbruikerstevredenheid te bewerkstellig. ' $n$ Beter begrip van die verbruiker se probleme, behoeftes en verwagtinge, in hierdie geval die vroeëadolessent s'n met betrekking tot die pas van haar klere, kan die kleinhandelaar in staat stel om die verbruiker beter te bevredig. Die doel van die studie is die ontwikkeling van ' $n$ konseptuele raamwerk wat in navorsing na die vroeë-adolessent se verwagtinge met betrekking tot die pas van haar klere, gebruik kan word. Vanuit die literatuur en vorige navorsing het dit duidelik geword dat fisieke, psigososiale en kognitiewe ontwikkeling tydens vroeëadolessensie ' $n$ rol mag speel in die verbruiker se verwagtinge en die probleme wat sy met die pas van haar klere mag ondervind. Verder dat haar begrip van die pas van klere asook haar spesifieke kognitiewe redenasie ' $n$ invloed mag hê op haar verwagtinge met betrekking tot die pas van haar klere asook die wyse waarop sy pas as deel van die kwaliteit van klere evalueer. Dit was verder duidelik dat dit vir haar moontlik nie net gaan om die funksionele dimensies van pas as deel van die kwaliteit van klere nie, maar veral ook om die estetiese dimensie van pas en wel dat die klere sensories mooi moet pas, haar emosioneel moet bevredig en vir haar bepaalde kognitiewe betekenis moet hê. Genoemde konsepte behoort deeglik in gedagte gehou te word in navorsing omtrent die vroeëadolessente dogter se verwagtinge met betrekking tot die pas van haar klere.

\section{- Ms T Tselepis}

Department of Consumer Science

University of Pretoria

- Prof HM de Klerk

Department of Consumer Science

University of Pretoria

\section{BACKGROUND}

Taking into account the problems experienced by the South African clothing industry and especially in retail, it is clear that retailers have to compete in a very focused way with others sharing the same market (Njobeni, 2003). For most retailers it is a priority to provide customer satisfaction. This endeavour is a long-term customer-oriented marketing strategy to retain loyal customers (Cronje et al, 2002:181). Sieben (1991), Hawkins et al (1998:22) and Solomon and Rabolt (2004:21) hold that it is a more advisable strategy to keep present consumers and keep them satisfied, rather than continually looking for new customers or focusing on a different market. According to Schiffman and Kanuk (2000:3) the only true competitive edge is to garner consumer satisfaction. To accomplish this, knowledge is required of their marketing needs, problems, expectations and similar aspects. Hawkins et al (1998:13) and Schiffman and Kanuk (2000:3) are of the opinion that a better understanding of consumer conduct will enable the retailer to satisfy customer needs, better see to their requirements and even to predict consumer behaviour.

From the clothing side Dickerson (2003:21) points out that the clothing industry finds it increasingly difficult to satisfy the consumer because, apparently, consumer priorities have changed markedly in the last decade. Where, during the eighties, consumers would easily have bought fashionable clothing and were prepared to pay an appreciable amount for a specific brand name, consumers are now generally more valuedriven and expect more for what they are prepared to pay. According to Ostroff, in Solomon and Rabolt (2004:21), the expectations of American clothing consumers were heightened during the previous decade as to what their clothes and the purchasing experience should signify for them. On the other hand, these consumers have become progressively less satisfied with what they were offered.

Word-wide and also in South Africa, little research has been done on early adolescents as a consumer market, especially regarding their evaluating criteria, expectations and problems relating to clothing. Adolescents normally have a great interest in clothes and in their own appearance. They use clothes to feel better about their bodies, to conform to their peer group and to conform to specific role models (Kelly et al, 1974; Kaiser, 1990:39; Sproles \& Burns, 1994:149; MacGillivray \& Wilson, 1997). According to Marshall et al (2004:18-21) the early adolescent market is one of the fastest growing clothing markets in America. The same could probably be said of the situation in South Africa. 
Early adolescence for girls is the ages between thirteen and fifteen, but it could begin as early as age eleven. It is also the period in the individual's life when drastic changes at the physical, socio-psychological and cognitive levels are taking place. These could have marked implications on the problems, needs and expectations about the clothing of the early adolescent. Taking into account the physical changes, it could be argued that it could affect the fit of her clothes. Ranges for children may no longer fit her while the sizes and proportions of adult ranges are also not suitable for her changing body. She may also not be satisfied with the styles available in the children's or adult ranges. The result is a dissatisfied consumer and more returns to the dealer due to clothes that do not fit properly.

In order to address the problem it is necessary, in the first instance that a comprehensive study be undertaken of the physical, socio-psychological and cognitive changes that take place during the early adolescent years and the implications that these might have on the fit of their clothes. Secondly, that fit is studied as part of quality evaluation of clothes when the consumer is in the process of making a purchasing decision $^{1}$.

\section{DEVELOPMENT OF THE EARLY ADOLESCENT CONSUMER}

Physical, socio-psychological and cognitive changes during early adolescence may influence these girls' expectations and problems regarding the fit of their clothes.

\section{Physical Development}

Physical development during early adolescence refers to the growth and changes of the early adolescent's body. Growth takes place relating to height, mass, bodily proportions and the development of secondary sexual characteristics. During this growth stage the body might appear out of proportion. Girls' growth already starts between the ages of nine and eleven years and peaks at about twelve and a half. Hips become broader and adipose tissue appears around the hips and legs, while the breasts are also developing markedly. One could speculate that these physical changes could influence her evaluation of her clothes and could possibly cause complications, especially regarding the fit of clothes. The fact that clothing retailers provide special clothing ranges for the adolescent doesn't necessarily satisfy the early adolescent's unique requirements about fit.

Physical changes of the body, however, are not only about the consequences that she might experience

\footnotetext{
${ }^{1}$ The term clothing means any thing that covers the body

The term clothing product/item refers to one single item, for example a skirt

The term clothes/garments refer to outer clothes, also known as apparel
}

about the actual, functional problems of the fit, such as too long or too narrow or that it is uncomfortable. The drastic physical bodily changes tend to lead to the investigation and study of the self, physically as well as socio-psychologically (Louw, 1990:404; MacGillivray \& Wilson, 1997). The ultimate appearance and fit of clothes should, therefore, not only be comfortable (i.e. functional) and pleasing to the senses (for example accentuating a slender waist). It also has to meet with her socio-psychological needs. The latter can never be judged separately from physical development.

\section{Socio-psychological development}

The early adolescent has a predominant need to belong to and to obtain recognition from the peer group (Kelley et al, 1974; Louw, 1990:441; MacGillivray \& Wilson, 1997). Most adolescents try to become independent of their parents and exchange this dependence on their parents to dependency on the peer group (Gormly \& Brodzinsky, 1989:324; Louw, 1990:442). The peers constitute a reference group to which the adolescent wants to belong and with whom she compares herself. In terms of clothing, fashion is used as a norm, indicating the dress code and how clothes should fit (Sproles \& Burns, 1994:149). The peer group is thus the group from whom the early adolescent girl wants to receive feedback about her clothing and her general appearance in relation to the norm set by fashion (Sproles \& Burns, 1994:141-149; Hawkins et al, 1998:215). MacGillivray and Wilson (1997) are of the view that clothing during adolescence is mainly used to show

Group-identity. The adolescent would, therefore, intentionally manage her appearance allowing the peer group to evaluate it as a guideline and acknowledge it as part of the peer group (Sproles \& Burns, 1994:150).

It is possible to infer therefore that the early adolescent, also as regards the fit of her clothes, wants to conform with the peer group and that it could probably cause problems for her. A possible problem that could result regarding the fit of clothes is that fashion styles don't necessarily suit all figure types. Fashion does probably guide the concepts of the early adolescent about what clothes are pretty and acceptable. However, the bodies of early adolescent girls don't necessarily resemble the bodies of the models who exhibit the clothes via the media. The media often creates an unrealistic image of bodies and the fit of apparel that the early adolescent tries to follow slavishly (Kaiser, 1990:129-131; Sproles \& Burns, 1994:147). The result is that adolescents and, specifically in this case, the early adolescent often experiences her body negatively and could experience problems about her body image (Kaiser, 1990:106; Parker et al, 1999:297-312).

Body image, according to Kaiser (1990:98) may be defined as the individual's perception of her own body, but also the feelings regarding her body. Early adolescents have, possibly because of bodily changes, definite problems about the fit of their clothes, and also because of the emphasis of the media and the peer group on the ideal body at this period, a negative body 
image (McClelland, 2000; Kowalski, 2000). They, therefore, not only have problems relating to the forming of realistic perceptions of their bodies, but also experience negative feelings about their bodies and, ultimately, also about their whole appearance and the total self. At this stage eating disorders such as anorexia nervosa or bulimia generally develop (Kowalski, 2000; Thompson \& Chad, 2000). One way of supporting the early adolescent to develop a positive body image, a positive self concept and an own identity is through her clothing. Her clothes should fit her in such a way that in wearing them, they satisfy her expectations, in that they suit her body, assist her in meeting the peer group's norms and let her feel she is in command of herself.

\section{Cognitive development}

The early adolescent girl finds herself in the formal, operational development phase of cognitive thought (Louw, 1990:418). She can now think in abstracts, for example that wearing a garment can have emotional and cognitive significances. The formal, operational thoughts are also applied to problem solving. She is capable to plan in detail and is able to test each alternative solution to a problem without actually doing it. She is now able to visualise a garment on herself without having to don it. However, to consider more than one alternative can frequently lead to confusion, for example when she has to make a choice between different clothing items during decision-making (Gormly \& Brodzinsky, 1989:308).

A possible problem for the early adolescent could be in terms of clothing purchases as a result of limited understanding (knowledge and experience) of garment fit and lack of knowledge about factors that influence fit, such as body shape, type of fabric and design. Understanding, according to Plug et al (1988:30) may be defined as a "cognitive, thus abstract and generalised impression of a thing or a class of things. The understanding takes together characteristics of things that are common to all members of a class and, what is important, to understand the thing and to distinguish it from others. Understanding is therefore defined by indicating to which class of things it belongs and by pointing out other distinguishing features...". Understanding thus includes the consumer's theoretical/ technical knowledge of fit of clothing products, but also knowledge based on previous experiences. This, however, doesn't include other cognitive and emotional needs relating to the fit of clothes.

The above definition of understanding agrees closely with the definition of a cognitive schema that is defined as a cognitive structure that contains knowledge about a concept/stimulus. A cognitive schema includes the characteristics of a concept and the relationship between the characteristics (Fiske \& Taylor, 1991:97, 98). A cognitive schema is, according to Fiske and Taylor (1991:97) a category that assists the individual to understand her environment. It contains generic knowledge and accentuates a person's active construction of reality. The inference follows that an understanding of a concept and a cognitive schema are synonymous. Understanding is thus defined from the standpoint of cognitive theory as a cognitive schema/framework that had developed from earlier theoretical knowledge or experience. The cognitive framework that the early adolescent girl has about the fit of clothes plays an important part in relation to her expectations and her evaluation of the fit of her clothes.

The importance of a cognitive schema resides in the fact that it influences the encoding of new information and that it contains a memory of previous information about concepts that enable a person to draw inferences from proof and argumentation (Fiske \& Taylor, 1991:121). Olson (1981:71) is of the opinion that one cannot make sense of a stimulus if it cannot be compared with existing knowledge and be fitted into a sensible category. DeLong et al (1986:17) conjecture that a cognitive schema includes a person's appreciation of the characteristics of a concept, situations of use and evaluation, and rules for decision-making. By implication this means that the clothing consumer's cognitive schema about a good fit could, for example, include her appreciation of fit (for example that the clothes should fit tightly), situations of use (to wear more daring clothes to an evening occasion), and evaluation or decision-making rules (such as when a garment will only be purchased if the hemline has a certain width).

Cognitive schemata of consumers differ because existing theoretical/technical knowledge, previous experiences and the specific situation where a decision has to be made, all differ. The fact that attention paid to a stimulus is selective by nature, can cause evaluation to be subjective. Hawkins et al (1998:291) consider that a person attends to stimuli regarding things in which a person has an interest in and can interpret. Therefore each consumer will take into account stimuli that she regards as important. It is only relevant knowledge that will be recalled during evaluation/ decision-making (Olson, 1981:70). By implication this means that the early adolescent girl probably has an existing schema about a suitable fit, that this schema includes her theoretical/technical knowledge about a good fit as well as previous experiences. Thus, when she evaluates the fit of a garment, she will evaluate the aspects of the garment that she finds important and compares it with her existing knowledge and her personal schema.

When making a suitable decision or evaluation, new information is integrated with existing knowledge structures (Olson, 1981:70). However, it is the view of Baron and Byrne (1997:91) that a person, when considering a purchase, doesn't necessarily go through the whole decision-making process every time. People often select an easier cognitive path to reach a decision. Two such cognitive shortcuts that consumers often use during the decision-making process and, specifically, during the evaluation of the product is the so-called false-consensus effect and the use of extrinsic factors as symbols of specific intrinsic factors or characteristics of the product. 
The early adolescent can evaluate the fit of a garment on basis of the false-consensus effect, which is the tendency of people to assume that all important others think in the same way (Baron \& Byrne, 1997:93). It is often used in a situation where the individual doesn't have a strong cognitive schema relating to the product or the situation (Schiffman \& Kanuk, 2000:145-147). The early adolescent could possibly use this shortcut as she can be very egocentric (Gormly \& Brodzinsky, 1989:310; Louw, 2000:145-147). This aspect will possibly also influence her evaluation of the garment's fit, as she might consider that her criteria for evaluating the fit are shared by everybody, especially by the peer group.

A second shortcut that is generally used by consumers is the use of specific extrinsic factors as indicative of specific intrinsic characteristics of the product again usually in situations where little knowledge exists about the intrinsic factors (Eckman et al, 1990; Schiffman and Kanuk (2000: 145-147). The inference can be drawn that extrinsic factors are also sometimes used to evaluate the fit of clothing items when the early adolescent has a limited understanding and thus little knowledge of and/or experience with the specific clothing product.

\section{EXPECTATIONS OF THE EARLY ADOLESCENT CONSUMER}

The question is: what does the foregoing imply for the expectations of the early adolescent when it comes to the fit of clothes? Expectations may be defined as the anticipation of an occurrence that will happen (Plug et al, 1988:322). Expectations are subjective by nature and serve as a standard for evaluating products (Dube \& Schmitt, 1991). Erasmus and Donoghue (1998) indicate that expectations arise from needs, normative standards, theoretical knowledge, recommendations by others and personal experience. Foxall and Goldsmith (1994:22-23) and Schiffman and Kanuk (2000:133-134) hold that consumers have certain expectations about the product and how the product will function. These expectations are the result of theoretical/technical knowledge of the product and what the product is able to accomplish, but also the result of previous experiences with the product, and is also based on socio-psychological needs that the product could possibly or has to satisfy. Therefore, it implies that the early adolescent may have certain expectations about how her clothes should fit, as well as what it ought to do and mean for her as a person. These expectations may be functional (such as that the clothes should fit comfortably), be aesthetic in appearance (in that it matches her figure well, or has a pleasing appearance), and also that the clothing should satisfy her socio-psychological needs. These expectations are, according to Solomon and Rabolt (2004:452) not only the result of her understanding of how clothes can and should fit (where this understanding is based on theoretical knowledge and/or previous experience), but also the result of her own socio-psychological needs and personal cognitive reasoning about her clothes and, here, specifically its fit. This implies that the expectations would not necessarily be realistic, but may even be totally unrealistic.

Taking into account the expectancy-disconfirmation theory, this implies then that unrealistic expectations could lead to cognitive disconfirmation when the consumer, in the after-sales situation, wearing the garment, realises that it in fact does not meet with her expectations (Solomon \& Rabolt, 2004:452). Consumer satisfaction is thus, in the opinion of Sieben (1991) and Solomon and Rabolt (2004:453-455) an after-sales evaluation of a product, judging whether the product realizes or surpasses the expectations of the consumer. This then relates to how the consumer had evaluated the characteristics of the product during the process of deciding about the purchase and, in this case, the fit of the item. Unrealistic expectations that were probably mainly based on the subjective use of cognitive shortcuts instead of being based on knowledge and experience about the product may result in an unsatisfied consumer. Figure 1 is a schematic representation of the above.

\section{From the schematic representation it is clear that:}

- The physical development of the early adolescent may result in her experiencing certain functional and appearance problems with the fit of her clothes, which in their turn might play a part in the expectations that she has about the fit.

- The socio-psychological development of the early adolescent may influence the needs that she has regarding the fit of her clothes, for example that it should agree with the norms of the group and the media, allow her to feel in control or dominant, and that these needs might impact on how she expects her clothes to fit her.

- She might have expectations about the functional fit of her clothes (in that it should be comfortable), the aesthetic appearance of her clothes (that it accentuates the best features of her body), as well as the socio-psychological aspects of the fit of her clothes (that it lets her feel in control or dominant, feminine, etc.).

- The cognitive development of the early adolescent, and specifically her understanding of the fit of clothes - whether as a result of earlier knowledge and experience or as the result of her cognitive reasoning and, specifically, the cognitive shortcuts that she may employ - may have an influence in the way she evaluates her clothing.

- The evaluation of the fit of her clothes cannot be judged separately from her expectations and also not divorced from the eventual satisfaction she may obtain from wearing the clothes.

- The eventual satisfaction when fitting clothes cannot be seen apart from the expectations that she had had about the fit.

The concept of fit within the evaluation of the quality of garments, however, is multi-dimensional by nature. Therefore attention is given to the concept of fit as part of quality evaluation. 


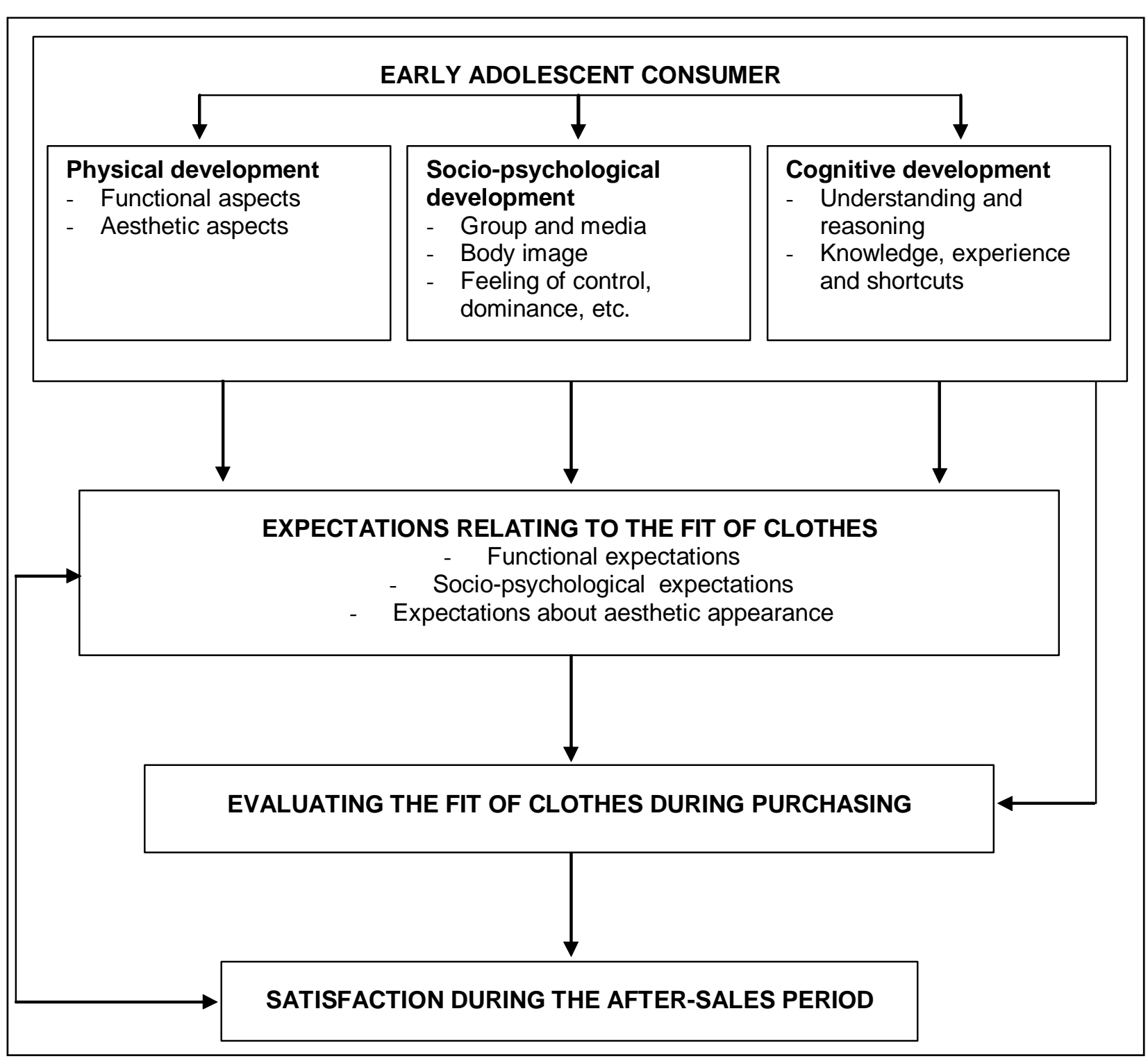

FIGURE 1:

THE RELATIONSHIP BETWEEN ADOLESCENT DEVELOPMENT, EXPECTATIONS AND EVALUATION OF FIT OF CLOTHES AND SATISFACTION DURING THE AFTER-SALES PERIOD

\section{FIT AS COMPONANT OF QUALITY EVALUATION OF CLOTHING}

\section{The concept of quality}

Research related to the significance of quality and the way whereby consumers evaluate the quality of products, especially clothing products, has been increasingly pleaded for since the eighties. Unfortunately, little research has been done in this area since the late-eighties and no relevant research in this area could be discovered that specifically refers to the evaluation by South African adolescent clothing consumers of the quality of clothing products.

The International Standards Organisation defines quality as the totality of characteristics of a whole that has the capacity to satisfy the explicit and implied needs of consumers (Brown \& Rice, 1998:37). According to Holbrooks, in Oliver (1996), quality is the reaction to the extrinsic clues of excellence, while Peters and Waterman, in Sieben (1991:66), see it as "... about $99,9 \%$ state of mind. It is attention to 'trivia' and the presence of persistence, not magic, that lead(s) to excellence". Broadly speaking, quality may be defined as the pre-eminence or excellence of a product, while observed quality can be taken to be the consumer's evaluation of the total of a product's pre-eminence or excellence (Zeithaml, 1998). According to Fiore and Damhorst (1992) the observed quality of a product, in this instance a clothing product, can be defined as the estimated capabilities of the product to provide satisfaction in relation to other alternatives. Zeithaml (1998) and Schiffman and Kanuk (2000:145-146) add 
that clothing consumers infer that this estimated capability to provide satisfaction, is derived from the intrinsic characteristics of the product it self, and also from other extrinsic variables.

\section{Quality judgement of clothing items/products}

From theory and research about the decision-making of the clothing consumer, it is clear that the evaluation of a clothing product is an important step in the decision-making process and that it includes aspects such as the evaluation of the quality of the product (Fiore \& Damhorst, 1992). According to Rogers and Lutz, in Fowler and Clodfelter (2001), the level of quality of a clothing product is a difficult factor to isolate and define when a clothing product has to be evaluated. However, quality is still regarded as one of the main reasons for a consumer's dissatisfaction with clothing products (Fowler \& Clodfelter, 2001).

Seen from the clothing marketing's perspective, Sieben (1991) and Yoon and Kijewski (1997) point out that the quality of clothing products is associated with the extent to which it satisfies the consumer's needs. Brown and Rice (1998:38-39) add that the quality of clothing products have two dimensions, namely, a physical dimension, specifying what the clothing item is, and a behavioural dimension indicating what the clothing item can achieve. As the physical features influence the behavioural characteristics, clothing consumers select clothing products because of the products' physical characteristics which they believe will then cause specific behaviour. Physical characteristics include the intrinsic factors of the product such as the design, textiles used, construction and finish that cannot be changed without changing the product itself. Sieben (1991), Brown and Rice (1998:38-39) and Gersak (2002) add that the behavioural characteristics of clothing products can be divided into functional as well as aesthetic behavioural characteristics. Functional behavioural characteristics refer to the durability of the clothing product, for example suitability for various purposes and occasions and that the clothing item will keep its appearance and structure when being worn and cared for, or that the clothing item fits comfortably. Aesthetic behavioural characteristics refer to the prettiness or aesthetic experience of the clothing item whether on a sensory level (e.g. in that the fabric doesn't bunch up), emotional (evoking specific feelings for the wearer), or cognitive (in that it has a certain symbolic significance for the wearer).

According to Abraham-Murali and Litrell (1995), Zeithaml (1998) and Brown and Rice (1998:43) consumers can evaluate a product at the point of purchase or when using it. They found that the comprehensive satisfaction of a consumer with the quality of a clothing item, such as its fit can be measured at the point of purchase, and also when the item is used and again when it is discarded. From the research it is, however, clear that clothing consumers, in many cases, do not intentionally evaluate the quality of the clothing item before, during or after the purchase of that item and that the quality, in many cases, is inferred from specific extrinsic indicators, such as the brand name or the store where it was bought. A specific brand name product may be beautiful for the early adolescent because it fits well on her body (satisfy her senses), or perhaps because it makes her feel in control (addressing the emotions), or maybe because it has significance for her seeing that she belongs to a specific group (cognitive).

Clothing consumers have specific expectations about the product as a result of previous experiences with a similar product or from available information that could possibly refer to quality (Muller, 1983; Solomon, 1996:325). Fiore and Kimle (1997:55), in addition, argue that the interaction between the clothing product and the body can further complicate the decision about whether to buy the clothing product because it doesn't only engender sensorial reactions from the consumer, but also emotional and cognitive reactions. The consumer is, therefore, not only concerned about the functional quality of the clothing product, but particularly about the comprehensive satisfaction regarding the sensorial, emotional and cognitive elements. From this a total aesthetic experience ensues for the consumer (Fiore \& Kimle, 1997:26). The ultimate goal of the evaluation of the quality of clothing products is that the consumer will be so satisfied with the product that it would lead to future purchases.

\section{The concept of fit}

Fit may be defined as the way a clothing item conforms to the body (Workman \& Lentz, 2000) or the relationship between the clothing item and the body (Ashdown \& DeLong, 1995). Stamper et al (1991:295) define a well-fitting garment as one that is comfortable to wear, with sufficient room to allow for easy movement, no unnecessary wrinkles and bunching of the fabric nor a display of bagginess, and that it should be aesthetically acceptable as well as fashionable. A clothing item with a good fit ought to conceal the wearer's figure faults, compliment the body and provide well-balanced proportions (Tate, 2004:65). A garment of the correct size, in combination with the correct body measurements ought to result in a notable fit (Tate, 2004:65). Liechty et al (2000:56-58) determined that a good fit is based on three factors, namely balance, room for movement and appearance. Balance means that the garment has to be donned to evaluate the hang of the constituent parts making up the garment and judging whether the whole garment is hanging on the body as it was intended to hang. At the same time all the seams have to be in their appointed places. Room for movement involves that aspect of sufficient space for easy movement when walking, ascending and descending stairs, sitting and kneeling down. Appearance means that the garment should not sidle into unsightly wrinkles, or present undesired bunching of the fabric, or start pulling in awkward directions.

With fit as a component of the quality of clothes, consumers are concerned in the first place with the functional characteristics of the fit. The garment must be comfortable with enough room for movement for a specific purpose. Secondly it has to fit well in that it 
flatters the body, hangs well and does not pull disconcertingly. Above all the garment must suit the occasion and the prescripts of fashion. From this theory it is clear that certain intrinsic factors of the garment, such as fabric, style and design, construction and size could influence the final fit of the garment. The aesthetic dimension is however, not only concerned with the sensorial appreciation of beauty, but also with the extent that the garment conforms to the sociopsychological needs of the wearer. Where intrinsic characteristics may primarily influence how well the garment fits, extrinsic factors have a part to play in the emotional and cognitive-aesthetic dimensions and thus satisfying of the socio-psychological needs of the wearer.

\section{Intrinsic factors that influence fit Fabric is an} important intrinsic factor that, according to Kadolph et al (1993:7), can influence the aesthetic appearance as well as the physical comfort of a garment. This means by implication that garments of different fabrics will look differently on a specific body, because they could hang differently or because of a difference in elasticity of the fabric. In this manner a garment with lots of elasticity would probably require less room for movement and ultimately influence the fit of the item.

Style/design is a second dimension that is important for the garment's suitable fit. Although style is influenced by fashion, it should accord with a specific figure type (Rasband, 1994:20; Tate, 2004:65). A garment, therefore, has to fit a specific figure to effect a well-fitting garment. Some styles are more suitable for some figures, while such styles would never look acceptable or be comfortable with other figures. It is, therefore, not only about freedom of movement, fabric and the size of the garment, but also about the choice of a specific style that would compliment a specific type of figure (Huck et al: 1997).

Brown and Rice (1998:139) explain that problems with fit could also be the result of bad construction, such as puckered and skew seams. To ensure a well-fitting garment it is finally necessary that the garment be of the correct size for that specific person. Brown and Rice (1998:131) point out that many consumers are not knowledgeable about taking measurements of their own bodies to enable them to decide on an appropriate sized garment. Furthermore, consumers lack certain knowledge of the way in which the size of garments is determined and how the sizes are indicated. This inability lessens their chances of obtaining wellfitting clothes.

Knowledge and experience of the intrinsic factors of clothing products that can influence these functional and aesthetic behavioural dimensions can thus support the early adolescent in her evaluation of the fit of her clothes because she can realistically evaluate the fabric, style/design, construction and size, taking into account her expectations about how her garments should fit. It is probably unrealistic to expect that the majority of consumers and more specifically the early adolescent will have any significant technical knowledge or experience of the construction of a garment and how that would ultimately influence the fit. It is probably more realistic to expect that the early adolescent has knowledge or experience about sizes, choice of style for her figure, and maybe the influence of the elasticity's of various fabrics. This knowledge could be used when quality is evaluated during decision making to ensure satisfaction when the clothes are worn. The last three intrinsic factors should therefore be included when researching the early adolescent's knowledge of and evaluating her ability to choose garments that fit well.

Extrinsic factors of fit The early adolescent also has socio-psychological needs that may influence her expectations about the fit of her clothes. Fiore and Kimle (1997:42) are of the opinion that clothing can be beautiful for the consumer and can satisfy her because it pleases her at the emotional and cognitive levels and can satisfy her socio-psychological needs. Although the intrinsic factors of a clothing item can also play a part here, consumers (especially when they lack knowledge and experience of the product) often use extrinsic factors and a particular way of thinking to satisfy these socio-psychological needs.

Gersak (2002), North et al (2003) and Tate (2004:366) argue that consumers usually use brand names, price and place of purchase, especially when they lack knowledge, to evaluate the garment's quality, which includes its fit. These extrinsic factors could also have a bearing on the satisfaction of the clothing consumer's socio-psychological needs because she can use them in her cognitive reasoning as symbols. It thus becomes meaningful for her and has nothing to do with the functional and beauty dimensions of the fit, but rather that she can use it to satisfy a specific socio-psychological need. A specific brand name exemplifies status or enables the consumer to function in a group. Taking into account the early adolescent's physical development it can also be argued that physical development and body growth can now often lead to specific problems of fit and that a negative body image often occurs in these years. A specific brand name could cause the early adolescent to feel more positive about her body, even if, from a purely technical viewpoint, the fit is not altogether correct. Finally, seen from the socio-psychological development of the early adolescent it is manifestly clear that the group is becoming increasingly important. The opinions of the group and the mass-media about the fit of clothes could be important in her expectations about how her clothing should fit (May \& Koester, 1985:232; Moschis, Moore \& Stanley in Shim \& Koh, 1997; Marshall et al, 2004:21). Based on the preceding discussion the schematic framework illustrated in Figure 2 is proposed.

From the schematic representation the following can be inferred:

- The intrinsic factors of the clothing item such as the fabric, style/design, construction and size can influence fit as component of the quality of the clothes.

- The behavioural characteristic of clothing items 


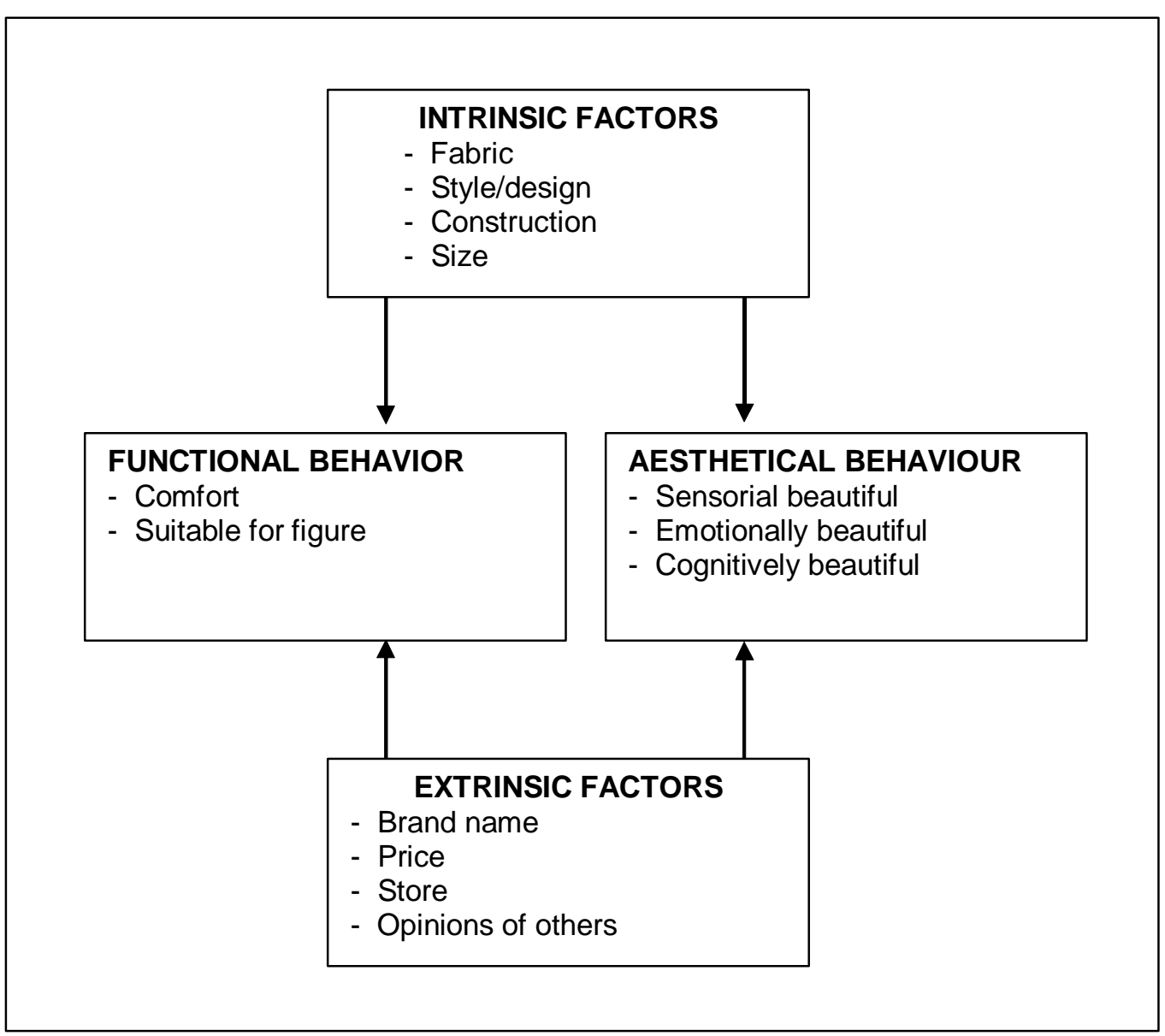

FIGURE 2: THE INFLUENCE OF INTRINSIC AND EXTRINSIC FACTORS ON THE FUNCTIONAL AND AESTHETIC BEHAVIOUR OF CLOTHING PRODUCTS

must include the functional behaviour, for example that the clothes should fit comfortably and be suitable for the figure, purpose, or occasion.

- Behavioural characteristics also include the aesthetic in that the fit creates an aesthetic experience. This means that not only should the fit be beautiful in that it flatters the figure or that the garment doesn't pull awkwardly, but also that it will be emotionally pleasing (for example creating a sense of dominance for the consumer in the group) and also that it will be cognitively-aesthetically beautiful (in that it has significance for her standing in the group).

- When the consumer has little or no knowledge and experience of the part played by the intrinsic factors and therefore is unable to relate those to the garment when evaluating its fit, she tends to make greater use of extrinsic factors such as brand name, price and similar aspects, to guide her as indicators for fit.

\section{PROPOSED CONCEPTUAL FRAMEWORK FOR RESEARCH}

Taking the above literature into account, the following schematic conceptual framework is proposed for re- searching early adolescent girls' expectations about the fit of clothes.

From the above schematic conceptual framework the following aspects can be inferred:

- The physical development and changing body of the early adolescent can cause certain problems with the fit of her clothes. She has specific functional needs regarding the fit of clothing. This has to do with the functional and aesthetic expectations that she has about the fit of her clothes, in that it should be comfortable and allow sufficient room for ease of movement, that it should suit her body, that it is suitable and has to be beautiful according to the occasion as well as the standards of fashion.

- Socio-psychological needs that the early adolescent might have and that probably also originate from her socio-psychological development is to be found, in the first place, at the emotional level. This means that she can through fit, provide positive support for her feelings about her body, or that it allows her to feel in control of herself or even being dominant in the group. Secondly this occurs at the cognitive level in that the brand name, price, store and satisfying the norms set by others (for exam- 


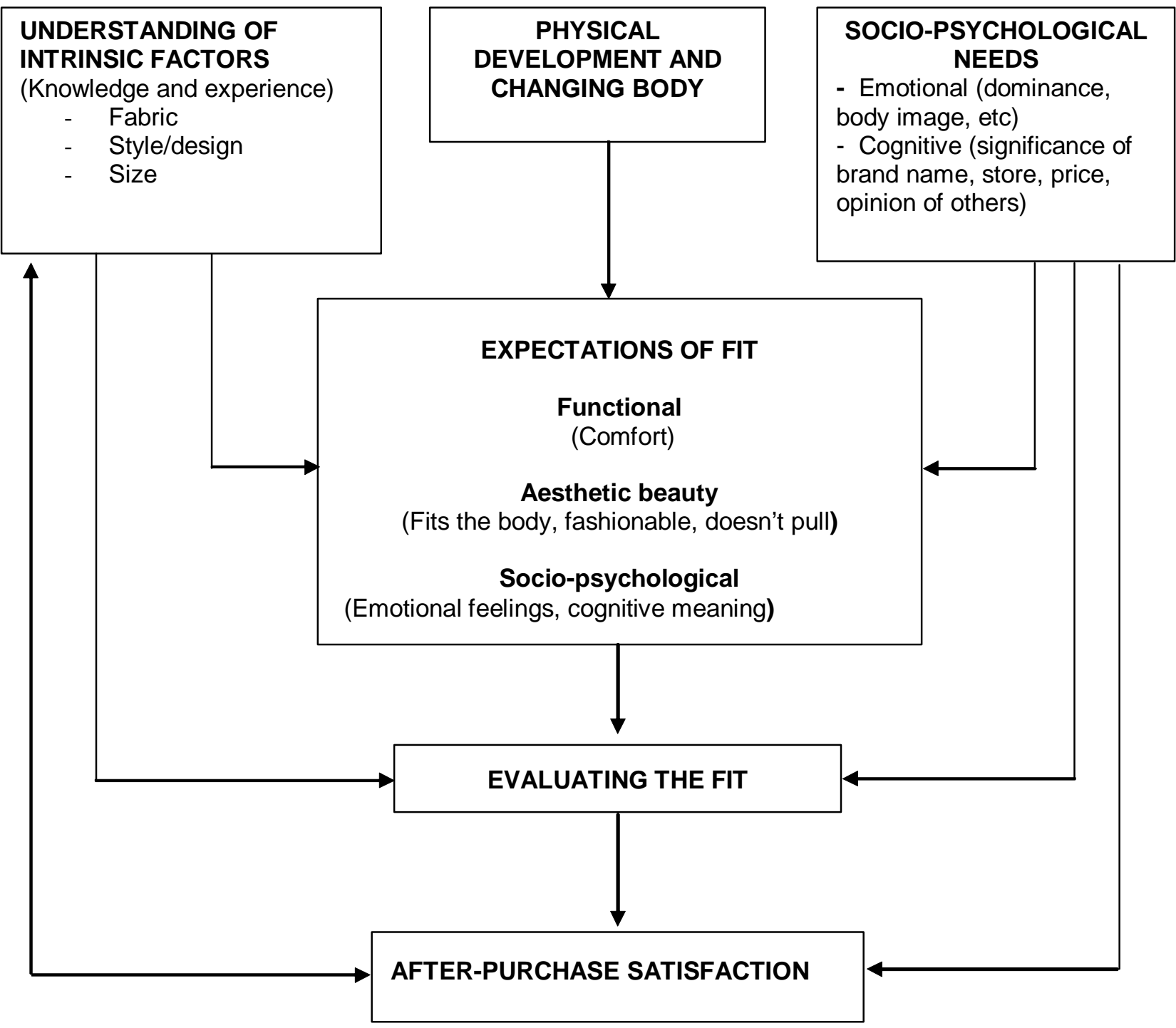

FIGURE 3:

PROPOSED SCHEMATIC CONCEPTUAL FRAMEWORK FOR RESEARCHING EARLY ADOLESCENT GIRLS' EXPECTATIONS ABOUT THE FIT OF CLOTHES

ple the peer group, mass media, current fashion) become significant for her and are indicative of her standing or that she is part of the group. These socio-psychological needs apparently influence the expectations that she has about the fit of her clothes. When evaluating the fit these needs may have such an overriding effect that she can ignore any consideration (in terms of knowledge and experience) of the contribution of the intrinsic factors of the clothing item. She is free to take cognitive shortcuts such as false-consensus or make subjective use of extrinsic indicators of fit such as price or brand name as indicator or symbol.

- Understanding (knowledge and experience) of the intrinsic factors of a clothing item that can influence fit, should play a part in the expectations that she has about the fit of her clothes, especially in relation with the functional and aesthetic expecta- tions. To realize her expectations it should, however, be used objectively during the evaluation of the fit of the clothing.

Unrealistic expectations or irresponsible evaluating, not based on theoretical/technical knowledge or previous experience could lead to cognitive disconfirmation when, after the item has been bought, the adolescent wears the item and then realises that it in fact does not comply with her requirements and that the soughtafter quality has not realized for her.

Considering the multi-dimensionality of the concepts as well as the fact that little is known about this consumer group's needs, problems and expectations regarding the fit of their clothing, it is suggested that a well considered conceptual framework that contains all indicators and relationship is used in research. It is 
further suggested that a combined quantitativequalitative research approach is used. This ought to provide the prospective researcher the opportunity not only to single out possible relationships between concepts, but also to determine other possible new dimensions as perceived by the consumer.

\section{REFERENCES}

ABRAHAM-MURALI, L \& LITTRELL, MA. 1995. Consumers' conceptualization of apparel attributes. Clothing and Textiles Research Journal 13(2):65-73. ASHDOWN, SP \& DELONG, M. 1995. Perceptual testing of apparel ease variation. Applied Ergonomics 26(1):47-54

BARON, RA \& BYRNE, D. 1997. Social psychology. $8^{\text {th }}$ ed. Boston. Allyn \& Bacon.

BROWN, P \& RICE, J. 1998. Ready-to-wear apparel analysis. $2^{\text {nd }}$ ed. Upper Saddle River, New Jersey. Prentice Hall.

CRONJE, GJ, DU TOIT, GS, \& MOTLATLA, MDC. 2002. Inleiding tot die bestuurswese. 5de uitgawe. Kaapstad. Oxford.

DELONG, MR MINSHALL, B \& LARNTZ, K. 1986. Use of schema for evaluating consumer response to an apparel product. Clothing and Textile Research Journal 5 (1):17- 26.

DICKERSON, KG. 2003. Inside the fashion business. $7^{\text {th }}$ ed. Upper Saddle River, New Jersey. Prentice Hall. DUBE, L \& SCHMITT, BH. 1991.The processing of emotional and cognitive aspects of product usage in satisfaction judgments. Advances in Consumer Research 18:52-56.

ECKMAN, M DAMHORST, ML \& KADOLPH, SJ. 1990. Toward a model of the in-store purchase decision process: consumer use of criteria for evaluating women's apparel. Clothing and Textiles Research Journal 8(2):13-22.

ERASMUS, A \& DONOGHUE, S. 1998. Consumer satisfaction: an unattainable ideal? Journal of Family Ecology and Consumer Sciences 26(1):35-42.

FIORE, AM \& DAMHORST, ML. 1992. Intrinsic cues as predictors of perceived quality of apparel. Journal of Consumer Satisfaction, Dissatisfaction and Complaining Behaviour 5:168-178.

FIORE, AM \& KIMLE, PA. 1997. Understanding aesthetics for the merchandising and design professional. New York. Fairchild.

FISKE, ST \& TAYLOR, SE. 1991. Social cognition. 2nd ed. New York. McGraw-Hill.

FOWLER, D \& CLODFELTER, R. 2001. A comparison of apparel quality: outlet stores versus department stores. Journal of Fashion Marketing and Management 5(1):57-66.

FOXALL, GR \& GOLDSMITH, RE. 1994. Consumer psycology for marketing. London. Routledge.

GERSAK, J. 2002. Development of the system for qualitative prediction of garments appearance quality. International Journal of Clothing Science and Technology 14 (3/4):169-180.

GORMLY LY, AV \& BRODZINSKI, DM. 1989. Lifespan human development. $4^{\text {th }}$ ed. Chicago. Holt, Rinehart \& Winston.

HAWKINS, DI, BEST, RJ, \& CONEY, KA. 1998. Con- sumer behavior: building a marketing strategy. $7^{\text {th }}$ ed. Boston. McGraw Hill.

HUCK, J, MAGANGA, O \& KIM, Y. 1997. Protective overalls: evaluation of garment design and fit. International Journal of Clothing, Science and Technology 9 (1): 45-61.

KADOLPH, SJ, LANGFORD, AL, HOLLEN, N \& SADDLER, J. 1993. Texliles. 7th ed. New York. Macmillan.

KAISER, S. 1990. The social psychology of clothing: symbolic appearances in context. $2^{\text {nd }}$ ed. New York. Macmillan.

KELLEY, EA DAIGLE, CW, LAFLEUR, RS, LAFLEUR, J \& WILSON, LJ. 1974. Adolescent dress and social participation. Home Economics Research Journal 2(3): 167-175.

KOWALSKI, KM. 2000. Focuses on the impact of eating habits on teenagers' overall health. Inset: Recognizing eating disorders. Current Health 27(4):6-12.

LOUW, DA. 1990. Menslike ontwikkeling. 2 de uitgawe. Pretoria. Haum.

LIECHTY, EG, POTTBERG, DN, \& RASBAND, JA. 2000. Fitting and pattern alteration: a multi-method approach. New York. Fairchild.

MACGILLIVRAY, MS \& WILSON, JD. 1997. Clothing and appearance among early, middle and late adolescents. Clothing and Textiles Research Journal 15(1): 43-50.

MARSHALL, SG, JACKSON, HO, STANLEY, MS, KEFGEN, M, \& TOUCHIE-SPECHT, P. 2004. Individuality in clothing selection and personal appearance. $6^{\text {th }}$ ed. Upper Saddle River, New Jersey. Prentice Hall.

MAY, JK \& KOESTER, AW. 1985. Clothing purchase practices of adolescents. Home Economics Research Journal 15(3): 226-236.

McCLELLAND, S. 2000. Distorted images: western cultures are exporting their dangerous obsession with thinness. MacLean's 41-46.

MULLER, JM. 1983. Verbruikerstevredenheid met tekstielprodukte. Tyskrif vir Dieëtkunde en Huishoudkunde 11(1):28-33.

NORTH, EJ, DE VOS, RB \& KOTZE, T. 2003. The importance of apparel product attributes for female buyers. Journal of Family Ecology and Consumer Sciences 31:41-51.

NJOBENI, S. 2003. SA's clothing industry in trouble. Moneyweb. Available on line. URL: http://mny.co.za/

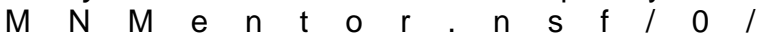
C2256A2A005298FAC2256DD50019F297?

OLIVER, RL. 1996. Varieties of value in the consumption satisfaction response. Advances in Consumer Research 23: 143-147.

OLSON, JC. 1981. Criteria for food acceptance. Zurich. Forster.

PARKER, S, NICHTER, M, NICHTER, M, VUCKOVIC, N, SIMS, C \& RITENBAUGH, C. 1999. Body image and weight concerns among African American and White adolescent females: differences that make a difference. In Damhorst, L, Miller, KA \& Michelman, SO.1999. The meanings of dress. New York. Fairchild.

PLUG, C, MEYER, WF, LOUW, DA \& GOUWS, LA. 1988. Psigologie-woordeboek. Johannesburg. Lexicon. 
RASBAND, J. 1994. Fabulous fit. New York. Fairchild. SCHIFFMAN, LG KANUK, LL .2000. Consumer behavior. $7^{\text {th }}$ ed. New York. Prentice-Hall.

$\mathrm{SHIM}$, S KOH, A. 1997. Profiling adolescent consumer decision-making styles. Clothing and Textiles Research Journal 15:50-59.

SIEBEN, WA. 1991. An interdisciplinary concept of apparel quality. International Textile and Apparel Association Special Publication 4:65-73.

SOLOMON, MR. 1996. Consumer behavior: buying, having, and being. $3^{\text {rd }}$ ed. Englewood Cliffs. Prentice Hall.

SOLOMON, MR \& RABOLT, NJ. 2004. Consumer behavior in fashion. Upper Saddle River, New Jersey. Prentice Hall.

SPROLES, GB BURNS, LD. 1994. Changing appearances: understanding dress in contemporary society. New York. Fairchild.

STAMPER, AA, SHARP, SH \& DONNEL, LB. 1991.
Evaluating apparel quality. $2^{\text {nd }}$ ed. New York. Fairchild.

TATE, S L. 2004. Inside fashion design. $5^{\text {th }}$ ed. Upper Saddle River, New Jersey. Prentice Hall.

THOMPSON, AM \& CHAD, KE. 2000. The relationship of pubertal status to body image, social physique anxiety, preoccupation with weight and nutritional status in young females. Canadian Journal of Public Health 91(3):207-211.

WORKMAN, JE \& LENTZ, ES. 2000. Measurement specifications for manufacturers' prototype bodies. Clothing and Textiles Research Journal 18(4): 251259.

YOON, E \& KIJEWSKI, V. 1997. Dynamics of the relationship between product features, quality evaluation and pricing. Pricing Strategy and Practice 5 (2):45-60.

ZEITHAML, VA. 1998. Consumer perceptions of price, quality, and value: a means-end model and synthesis of evidence. Journal of Marketing 52: 2-22. 